\title{
The size of native milk fat globules affects physico-chemical and functional properties of Emmental cheese
}

\author{
Marie-Caroline MICHALSKI*, Bénédicte CAMIER, Valérie BRIARD, \\ Nadine LECONTE, Jean-Yves GASSI, Henri GoUdÉDRANCHE, \\ Françoise MiCHEL, Jacques FAUQUANT \\ UMR Science et Technologie du Lait et de l'Oeuf, INRA-Agrocampus, \\ 65, rue de Saint-Brieuc, 35042 Rennes Cedex, France
}

Received 19 November 2003 - Accepted 19 February 2004

Published online 7 June 2004

\begin{abstract}
Emmental cheeses were produced using either small $(\sim 3 \mu \mathrm{m}, \mathrm{SFG})$ or large $(\sim 6 \mu \mathrm{m}$, LFG) native milk fat globules obtained by a patented microfiltration process. Ripened SFG cheeses were less flexible and less firm than LFG cheeses. Indeed, the SFG cheeses contained more moisture and underwent greater proteolysis than the LFG cheeses $52 \mathrm{~d}$ after manufacture. However, lipolysis was three-fold lower in SFG cheeses. This was linked to the milk fat structure in Emmental cheese: larger inclusions of denuded destabilized fat were observed in LFG cheeses, whereas more fat globules were observed in SFG cheeses. One Emmental cheese was produced using homogenized milk fat globules, in which lipolysis was dramatically increased and unacceptable. For a given size range, the structure of milk fat is thus of tremendous importance regarding lipolysis and small natural milk fat globules cannot be replaced by homogenized ones. The melting temperature and solid fat content of fat in Emmental cheese increased with native fat globule size. This is related to the improved functional properties of SFG cheeses, i.e., increased stretching, elastic increase and melting, and lower extrusion force compared with LFG cheeses. This study confirms, as previously pioneered using Camembert cheese manufacturing technology, that the use of native milk fat globules with different sizes can lead to a range of new dairy products with different physico-chemical and functional properties.
\end{abstract}

Milk fat / fat globule / Emmental cheese / cheese yield / rheology / particle size / microfiltration / functional property

Résumé - Des propriétés physico-chimiques et fonctionnelles de l'emmental sont affectées par la taille des globules gras natifs du lait. Des emmentals ont été fabriqués en utilisant des globules gras natifs du lait de petit diamètre $(\sim 3 \mu \mathrm{m})$ ou de grand diamètre $(\sim 6 \mu \mathrm{m})$, obtenus par un procédé de microfiltration breveté. Les fromages affinés à petits globules sont moins souples et moins fermes que ceux à gros globules. En effet, les fromages à petits globules sont plus humides et plus protéolysés à $52 \mathrm{j}$ d'affinage. Cependant, la lipolyse est trois fois moindre dans les fromages à petits globules, ce qui est lié à la structure de la matière grasse dans les emmentals : les emmentals à gros globules présentent de plus grandes inclusions de matière grasse déstabilisée, tandis que ceux à petits globules semblent contenir plus de globules gras. Un emmental a été fabriqué avec des globules

\footnotetext{
* Corresponding author: mcmichal@labtechno.roazhon.inra.fr
} 
homogénéisés, ce qui a conduit à une lipolyse bien plus importante et inacceptable sensoriellement. Ainsi, pour une taille de globules gras donnée, la structure de la matière grasse est très importante en ce qui concerne la lipolyse et des globules homogénéisés ne peuvent pas remplacer des petits globules natifs. Le point de fusion et la teneur en solides de la matière grasse dans les emmentals augmentent avec la taille des globules gras natifs. Ceci peut expliquer les meilleures aptitudes fonctionnelles des emmentals à petits globules, c'est-à-dire, de meilleurs filant, gain d'élasticité et fondant, et une force d'extrusion plus faible que les emmentals à gros globules. Comme nous l'avions mis en évidence précédemment dans le cadre d'une toute autre technologie fromagère (camembert), cette étude confirme que l'utilisation de globules gras natifs du lait de tailles différentes permet de développer de nouveaux produits laitiers avec différentes propriétés physico-chimiques et fonctionnelles.

Matière grasse du lait / globule gras / emmental / rendement fromager / granulométrie / rhéologie / propriété fonctionnelle / microfiltration

\section{INTRODUCTION}

The texture, flavor and physico-chemical properties of cheese are greatly governed by the milk fat [15]. More than $95 \%$ of the mass of lipids in cow's milk is present in the form of spherical milk fat globules (MFG) [16], with a diameter ranging from $0.1 \mu \mathrm{m}$ to $15 \mu \mathrm{m}$ and a volumetric average around $4 \mu \mathrm{m}$ [33]. They are surrounded by a native biological membrane, allowing them to be compatible with the aqueous environment: the milk fat globule membrane (MFGM). Considering the average milk fat globule size distribution, the MFGM surface area is $\sim 1.85 \mathrm{~m}^{2} \cdot \mathrm{g}^{-1}$ fat, i.e., $\sim 75 \mathrm{~m}^{2} \cdot \mathrm{kg}^{-1}$ milk [24]. The smallest MFG $(<1 \mu \mathrm{m})$ represent more than $80 \%$ of the total number of globules, although a few percent of the fat volume, and have a much higher specific surface area. A few large globules $(>10 \mu \mathrm{m})$ also exist, comprising about $2 \%$ of the fat, with a lower specific surface area [33]. It has been shown that small and large MFG slightly differ in composition, the smallest native globules containing more short-chain fatty acids and less C18 [2].

The structure and texture of cheese are affected by the interactions between the surface of milk fat globules and the casein matrix. In this respect, native MFG do not interact with the protein network in dairy gels and act mainly as inert fillers or structure breakers, depending on their size and number. In a first study, we have shown that the size of native MFG resulted in different physico-chemical and sensory properties of Camembert cheese, in which fat remains essentially in its globular form [26]. The native milk fat globules of different sizes were obtained by a microfiltration process [9]; the small globules obtained this way were native, conversely to globules formerly obtained by homogenization, that were disrupted and covered by caseins.

Emmental cheese represents $24 \%$ of French ripened cheese production, with $247000 \mathrm{t}$ produced in 1999. Moreover, this manufacture increased by $30 \%$ between 1982 and 1997, partly due to the processed cheese market, $140000 \mathrm{t}$ of Emmental cheese being used hot for culinary purposes [5]. Therefore, there is a growing demand for improving the functional properties of Emmental cheese and finding new uses, while keeping the product economically attractive. Until the recent works by Famelart, Richoux and colleagues [5, 27], most articles regarding functional properties and their relationship with composition and rheological properties dealt with other types of cheese, e.g., Mozarella [22]. The water content has been shown to be a major parameter affecting the functional properties of Emmental cheese [5, 27]. The fat composition can hardly be adjusted since native milk fat globules are used and to date, no study has attempted to test the effect of 
native milk fat globule properties on the composition and functional properties of Emmental cheese.

The aim of the present work was to investigate the influence of the size of the native milk fat globules on the physicochemical and functional characteristics of Emmental cheese, in which globular structure may be partly disrupted, using milk fractions with small $(\sim 3 \mu \mathrm{m})$ or large $(\sim 6 \mu \mathrm{m})$ fat globules obtained by microfiltration.

\section{MATERIALS AND METHODS}

\subsection{Emmental cheese manufacture}

Three series of Emmental cheese manufactures with different sizes of fat globules were performed in January in a special pilot plant in the laboratory (Chalon Megard, La Cluse, France). The results presented are the average of the different assays. Three standard Emmental cheeses were produced with regular raw whole milk; however, for confidentiality reasons, these results cannot be presented in this article.

Day D-1. Raw whole milk purchased from a local dairy plant (Triballat, Noyal-surVilaine, France) was collected and stored at $4{ }^{\circ} \mathrm{C}$ the day before Emmental production (D-1). The milk was microfiltered with a uniform transmembrane pressure according to a process patented in the laboratory [9]. Appropriate membrane pore sizes and hydrodynamic conditions were used, so as to obtain two milk fractions differing in the diameter of fat globules, namely, around 3 and $6 \mu \mathrm{m}$, respectively. The corresponding fractions will be called small fat globule (SFG) and large fat globule (LFG) fractions. Because of the proprietary nature of this work, further details of the microfiltration process are not available for publication. The LFG milk was adjusted to a fat content:total nitrogen ratio (Fat:TN) of 0.85 using skimmed milk. Part of the SFG fraction was concentrated using a cream separator (Westfalia, Château-Thierry, France) and was then adjusted to a Fat:TN ratio of 0.85 using the rest of the SFG fraction. It was checked that the milk fat globules remained native and were not disrupted by the microfiltration process by measuring the globule $\zeta$-potential, with the procedure and apparatus described by Michalski et al. [25].

In order to compare small native milk fat globules with homogenized ones (HFG), part of the initial raw whole milk was homogenized at $3 \mathrm{MPa}$ at $50{ }^{\circ} \mathrm{C}$ (RannieAPV, Evreux, France) to produce one Emmental cheese with disrupted globules (covered by caseins and whey proteins instead of the native MFGM) but with a diameter similar to the SFG milk. The homogenized milk was adjusted to a Fat:TN ratio of 0.85 using skimmed milk. Thus during the three manufactures, three SFGcheeses, two LFG-cheeses and one HFGcheese were produced.

Standardized milk samples were heated at $63{ }^{\circ} \mathrm{C}$ for $20 \mathrm{~s}$ in a pilot pasteurizer (Actijoule, Actini, Evian, France).

Day $D$. Milk was heated at $32{ }^{\circ} \mathrm{C}$ in the milk vat. It was supplemented with $0.01 \mathrm{~mL} \cdot \mathrm{kg}^{-1}$ of lysozyme solution (Delvosyme, Gist Brocades, Seclin, France) and $0.01 \mathrm{~mL} \cdot \mathrm{kg}^{-1}$ of a $510 \mathrm{~g} \cdot \mathrm{L}^{-1} \mathrm{CaCl}_{2}$ solution. The milk was inoculated as follows: lactococci (EZAL MM100, Rhodia, DangéSaint-Romain, France) Lactococcus lactis subspp. lactis, cremoris and lactis biovar diacetylis (0.003 U. $\left.\mathrm{kg}^{-1}\right)$; thermophilic lactobacilli (PAL ITG LH56-LL57, Standa, Caen, France) Lactobacillus helveticus and Lactobacillus delbruecki lactis ( $10^{5}$ colonyforming units $\cdot \mathrm{kg}^{-1}$ ); propioni bacteria (PAL ITG P9, Standa, France) Propionibacterium freudenreichii subsp. shermanii $\left(0.06 \mathrm{~g} \cdot \mathrm{kg}^{-1}\right)$; thermophilic streptococci (PAL ITG ST 82-87, Standa, France) Streptococcus thermophilus - the commercial strain was first grown at $42{ }^{\circ} \mathrm{C}$ for $4.5 \mathrm{~h}$ on Marstar 412A medium (Rhodia, France), it was then inoculated in the milk at $1 \mathrm{~mL} \cdot \mathrm{kg}^{-1}$.

After 30 min maturation at $32{ }^{\circ} \mathrm{C}$, the milk $\mathrm{pH}$ was adjusted to $6.60-6.62$ using 
$\mathrm{CO}_{2}$ dissolved directly in milk. Calf rennet was added (IMCU: 145, Berthelot, ABIA S.A., Meursault, France) at $0.025 \mathrm{~mL} \cdot \mathrm{kg}^{-1}$. The gel hardened in $20 \%$ of the clotting time, i.e., after 20 to $22 \mathrm{~min}$. It was cut, and the curd grains were mixed and heated for $30 \mathrm{~min}$ up to a temperature of $51{ }^{\circ} \mathrm{C}$. The curd was drained off under vacuum $(30 \mathrm{kPa})$ in the racking unit and moulded in a $780 \mathrm{~mm}$-diameter mould (Doryl, France). The curd was pressed for $4 \mathrm{~h}$ at $0.39 \mathrm{kPa}$. Whey was collected and weighed. After pressing, the curd was turned over and acidified for $20 \mathrm{~h}$ in a thermostatic chamber at $24{ }^{\circ} \mathrm{C}$.

Day $D+1$. The curd was demoulded, weighed and brined for $48 \mathrm{~h}$ at $12{ }^{\circ} \mathrm{C}$ in a saturated $\mathrm{NaCl}$ solution $\left(350 \mathrm{~g} \cdot \mathrm{L}^{-1}\right)$ at $\mathrm{pH}$ 5.2 .

The cheese was ripened for $21 \mathrm{~d}$ at $12{ }^{\circ} \mathrm{C}$, $85 \%$ relative humidity; then $21 \mathrm{~d}$ at $20^{\circ} \mathrm{C}$, $80 \%$ relative humidity, and finally, $10 \mathrm{~d}$ at $4{ }^{\circ} \mathrm{C}$. Emmental cheeses were weighed at $\mathrm{D}+1, \mathrm{D}+7, \mathrm{D}+21$ and $\mathrm{D}+52$. They were cut for complete final analyses at D+52. This ripening time corresponds to 10 days more than the French legal ripening period (6 weeks [5]).

\subsection{Biochemical and physico- chemical analyses}

Cheese samples were analyzed after 1 and $52 \mathrm{~d}(\mathrm{D}+1, \mathrm{D}+52)$. At $\mathrm{D}+1$, cylindrical samples $(15 \mathrm{~cm}, \sim 80 \mathrm{~g})$ were taken from the cheese surface and at mid-radius using a specific tool (ITFF, Rennes, France). At $\mathrm{D}+52,2 \mathrm{~cm}$ of crust was removed from a piece corresponding to an eighth of the cheese; then a sample of $20 \times 6 \times 4 \mathrm{~cm}$ $(\sim 500 \mathrm{~g})$ was cut at mid-radius.

The $\mathrm{pH}$ was measured at $\mathrm{D}+1$. Total solids (TS) were estimated by drying $2 \mathrm{~g}$ of cheese mixed with sand at $102{ }^{\circ} \mathrm{C}\left( \pm 2{ }^{\circ} \mathrm{C}\right)$ for $7 \mathrm{~h}$ [7]. Fat content was determined using the SBR method [6]. Total nitrogen (TN) in the cheeses was obtained from nitrogen analysis using the Kjeldahl method [8]. For all samples, the protein breakdown was measured by the evolution of soluble nitrogen at $\mathrm{pH} 4.6$ (NCN, non-casein nitrogen), and $12 \%$ TCA-soluble nitrogen (NPN, nonprotein nitrogen), according to the method described by Gripon et al. [10]. To quantify the evolution of proteolysis, the following ratios were calculated: NPN/TN and (NCNNPN)/TN, expressed as a percentage of the cheese TN content. Analyses were performed in triplicate.

Moisture in non-fat substance (MNFS, $\%)$ was calculated as follows: MNFS = $(1000-T S) /(1000-$ Fat content $) \times 100$. Fat in dry matter (FDM, \%) was calculated as follows: $\mathrm{FDM}=\mathrm{Fat} / \mathrm{TS} \times 100$. The corrected cheese yield was calculated according to Maubois and Mocquot [21]. Water activity of ground cheese samples that were cut at mid-radius was measured using an automated $\mathrm{a}_{\mathrm{w}}$-meter (Novasina, Pfäffikon, Switzerland) at $20^{\circ} \mathrm{C}$.

Free fatty acid analysis was performed by gas chromatography with internal standard by ITERG (Pessac, France) according to de Jong and Badings [3]. Sugar and organic acid were measured by HPLC [17]: cheese was diluted in distilled water at $40{ }^{\circ} \mathrm{C}$, disrupted with a high-shear mixer for $2 \mathrm{~min}$ at $20400 \mathrm{rpm}$, and incubated for 60 min in a water-bath at $40^{\circ} \mathrm{C}$, prior to centrifugation at $3000 \times g, 30 \mathrm{~min}, 4^{\circ} \mathrm{C}$. Supernatant was filtered on Whatman paper 40 and diluted with the same volume of $\mathrm{H}_{2} \mathrm{SO}_{4}$ at $0.01 \mathrm{~mol} \cdot \mathrm{L}^{-1}$. Precipitated proteins were discarded by filtration and the clear solution was collected for injection in the HPLC chromatograph (Beckman Coulter Corp., Fullerton, California) using a column packed with an ion-exchange resin Aminex A-6 (BioRad, Hercules, California), at $55^{\circ} \mathrm{C}$. Mobile phase was $\mathrm{H}_{2} \mathrm{SO}_{4}$ at $0.01 \mathrm{~mol} \cdot \mathrm{L}^{-1}$ and $1 \mathrm{~mL} \cdot \mathrm{min}^{-1}$. Organic acids were measured with a UV detector $(210 \mathrm{~nm})$ while sugars were determined refractometrically.

\subsection{Size distribution measurements}

The particle size distribution of standardized milk was measured by laser light scattering (LLS) using a Mastersizer 2000 
(Malvern Instruments, Malvern, UK) as previously described [23]. From the size distribution, the average diameter $\mathrm{d}_{43}=$ $\Sigma\left(\mathrm{v}_{\mathrm{i}} \times \mathrm{d}_{\mathrm{i}}\right) / \Sigma \mathrm{v}_{\mathrm{i}}$ was calculated by the software (where $v_{i}$ is the volume of globules in a size class of diameter $\mathrm{d}_{\mathrm{i}}$ ) as well as the specific surface area S. In order to estimate the fat particle size distribution within the Emmental cheese at D+52,1 $\mathrm{g}$ of the casein matrix was dissociated with $4 \mathrm{~mL}$ of dissociation buffer $\left(6 \mathrm{~mol} \cdot \mathrm{L}^{-1}\right.$ urea, $100 \mathrm{mmol} \cdot \mathrm{L}^{-1}$ EDTA, $20 \mathrm{mmol} \cdot \mathrm{L}^{-1}$ imidazole buffer $\mathrm{pH}$ 7) and shaken gently for $2 \mathrm{~h}$ prior to measurement [26].

\subsection{Rheological measurements}

Rheological properties of Emmental cheese at D+52 were measured with a universal testing machine (Instron, model 4501) using the IX series software, equipped with a $1 \mathrm{kN}$ load cell and a plate of $60 \mathrm{~mm}$. Sampling was performed on the Emmental cheese at $4{ }^{\circ} \mathrm{C}$ and involved the cutting of $\approx 10$ plugs $(20 \mathrm{~mm}$ in diameter and $20 \mathrm{~mm}$ height) $4 \mathrm{~cm}$ from the higher and lower edges and $10 \mathrm{~cm}$ at least from the heel. Plugs were stored at $20^{\circ} \mathrm{C}$ for at least $1 \mathrm{~h}$ in an aluminium foil prior to compression. The crosshead speed was of $30 \mathrm{~mm} \cdot \mathrm{min}^{-1}$ over a $17-\mathrm{mm}$ distance. The rheological parameters were the fracture stress $(\mathrm{Pa})$, the fracture Hencky's strain [32] and the stiffness $\left(\mathrm{N} \cdot \mathrm{m}^{-1}\right)$. Stress data were corrected for the increase in the plug surface during compression assuming a constant sample volume.

\subsection{Confocal laser scanning microscopy (CLSM)}

Small pieces of cheese were taken from the whole Emmental cheese and put in isopentane cooled by liquid nitrogen at $-150^{\circ} \mathrm{C}$, in order to freeze the samples without formation of ice crystals. Twenty- $\mu$ m-thick sections were achieved at $-27{ }^{\circ} \mathrm{C}$ using a cryotome. After drying on a slide, sections were colored by a few drops of a solution containing Fluorescein Iso Thyo-Cyanate (FITC), labeling the proteins, and Nile Red, for the labeling of lipids. After $30 \mathrm{~min}$, sections were rinsed using distilled water, and an upper lip was sealed on the section using nail polish.

Microscopic observations were performed using a Zeiss LSM Confocal microscope (Zeiss, Le Pecq, France) used in epi mode [13]. Excitation of Nile Red was performed using a laser of wavelength $543 \mathrm{~nm}$, and the emission of fluorescence was recorded between 575 and $640 \mathrm{~nm}$, hence enabling the localization of lipids. In order to detect the proteins, FITC was excited at $488 \mathrm{~nm}$ and the emission of fluorescence was recorded between 510 and $525 \mathrm{~nm}$. The conditions used ensure a good spectral discrimination.

Fluorescence images obtained for each component can be transferred into different channels, thus attributing a color to each component. The superimposition of the pictures shows the relative distribution of the components in the system, protein appearing in blue and lipids in red.

\subsection{Functional properties and color}

Functional properties of Emmental cheese at $\mathrm{D}+52$ were characterized by the Institut Technique Français des Fromages (ITFF, Rennes, France) as described in detail by Richoux et al. [27]. A butyrometric method was applied to quantify oiling-off; briefly: shredded cheese was heated at $65{ }^{\circ} \mathrm{C}$ in a butyrometer, after addition of water and centrifugation, free oil quantity was read at $65^{\circ} \mathrm{C}$. Stretchability was assessed by a method involving vertical traction at $1015 \mathrm{~mm} \cdot \mathrm{min}^{-1}$, $82{ }^{\circ} \mathrm{C}$ with a Universal Testing Machine (Instron, Guyancourt, France). The melting coefficient (flowability) was measured using a modified Schreiber test. The so-called elasticity increase was calculated as the ratio of hot and cold extrusion forces of the defatted cheese, the cold extrusion force being an index of cheese chewiness. Extrusion force was measured on the fat cheese [29].

The color of SFG and LFG Emmental cheese was measured objectively in our 
laboratory with a color meter Chromameter CR300 (Minolta, Carrières-sur-Seine, France), resulting in the $\mathrm{L}, \mathrm{a}, \mathrm{b}$ parameters that were first converted into the $\mathrm{X}, \mathrm{Y}, \mathrm{Z}$ system as follows : $\mathrm{L}=116 \times(\mathrm{Y} / 100)^{1 / 3}-16$; $\mathrm{a}=500 \times\left[(\mathrm{X} / 95.045)^{1 / 3}-(\mathrm{Y} / 100)^{1 / 3}\right] ; \mathrm{b}=$ $200 \times\left[(\mathrm{Y} / 100)^{1 / 3}-(\mathrm{Z} / 108.892)^{1 / 3}\right]$. The Yellow Index was then calculated as: $(1.301 \times \mathrm{X}-1.149 \times \mathrm{Z}) / \mathrm{Y}$ [28]. Five measurements were performed for each cheese sample when cut.

\subsection{Differential scanning calorimetry}

The thermal properties of Emmental cheese were measured by DSC (differential scanning calorimetry; Q-1000, TA Instruments, Saint-Quentin-en-Yvelines, France). Cheese samples were cut at mid-radius. Two to $4 \mathrm{mg}$ of ground sample were weighed in a hermetic aluminum pan of $50 \mu \mathrm{L}$. An empty hermetic aluminum pan was used as reference. Calibration was made with indium. The sample was equilibrated for $24 \mathrm{~h}$ at $4{ }^{\circ} \mathrm{C}$ in order to stabilize triglyceride crystalline structures; then it was kept at $0{ }^{\circ} \mathrm{C}$ for 10 min prior to melting at $10^{\circ} \mathrm{C} \times \mathrm{min}^{-1}$ up to $60^{\circ} \mathrm{C}$. Measurements were performed in triplicate.

\subsection{Statistical analysis}

An unbalanced factorial design was used; average and standard deviation were calculated for all the variables, on each homogeneous cheese group consisting of 3 individuals for SFG cheese and of 2 individuals for LFG cheese (each individual is related to the average of 3 to 10 measurements, depending on the variable). The StatGraphics Plus software (Manugistics, Rockville, USA) was used to perform analysis of variance. A Fisher test was carried out with a Least Significant Difference procedure by size, to test the significance of result differences between the SFG and LFG results (1\% risk of considering a significant difference when the actual difference equals zero). Below, a significantly different result means $P<0.05$ and a very significantly different result means $P<0.01$.

\section{RESULTS AND DISCUSSION}

\subsection{Milk composition and Emmental cheese manufacture parameters}

The $\zeta$-potential of SFG was $-13.4 \pm 0.2$ $\mathrm{mV}$ and that of $\mathrm{LFG}-13.6 \pm 0.1 \mathrm{mV}$, which is the same value as that of the original globules from whole milk and shows that the fat globules remained native throughout the microfiltration process [25]. The milk fat globule size distribution of SFG and LFG milks is shown in Figure 1 and the mean fat globule diameters are presented in Table I. Furthermore, the Emmental cheese produced with homogenized milk fat globules contained globules with $\mathrm{d}_{43}=2.10 \mu \mathrm{m}$ vs. $3.31 \pm 0.06 \mu \mathrm{m}$ for native SFG cheese.

As shown in Table I, the composition of the SFG and LFG milks used to prepare the cheeses was not significantly different, only the fat globule diameter differed. Moreover, the fat globule size did not affect technological parameters such as manufacture times and the kinetics of $\mathrm{pH}$ decrease.

\subsection{Whey composition}

Whey extracted after moulding of SFG cheese and HFG cheese contained more fat than whey from LFG cheese, certainly because the numerous small fat globules can escape more easily from the curd; other components did not differ (Tab. I). After pressing, however, all wheys had similar composition except for TS. One should note that the wheys contain smaller and smaller fat globules compared with the original milk: $3.19 \pm 0.12 \mu \mathrm{m}$ in whey after moulding of SFG cheese vs. $5.09 \pm 0.40 \mu \mathrm{m}$ for LFG, $2.14 \pm 0.12 \mu \mathrm{m}$ in whey after pressing of SFG cheese vs. $4.43 \pm 1.25 \mu \mathrm{m}$ for LFG. 


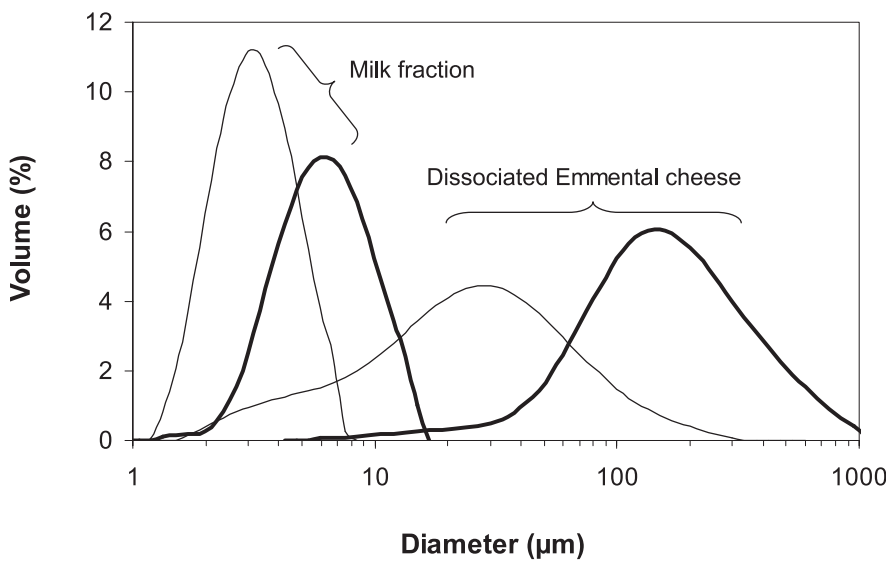

Figure 1. Particle size distribution of small (thin lines) and large (thick lines) fat globules (i) in cheese milk and (ii) in cheese curd $52 \mathrm{~d}$ after manufacture after dissociation of the casein matrix by EDTA, urea and SDS (typical example).

Table I. Physico-chemical properties and composition of the milk and fat globule used to produce Emmental, and of the whey extracted from the corresponding Emmental curd.

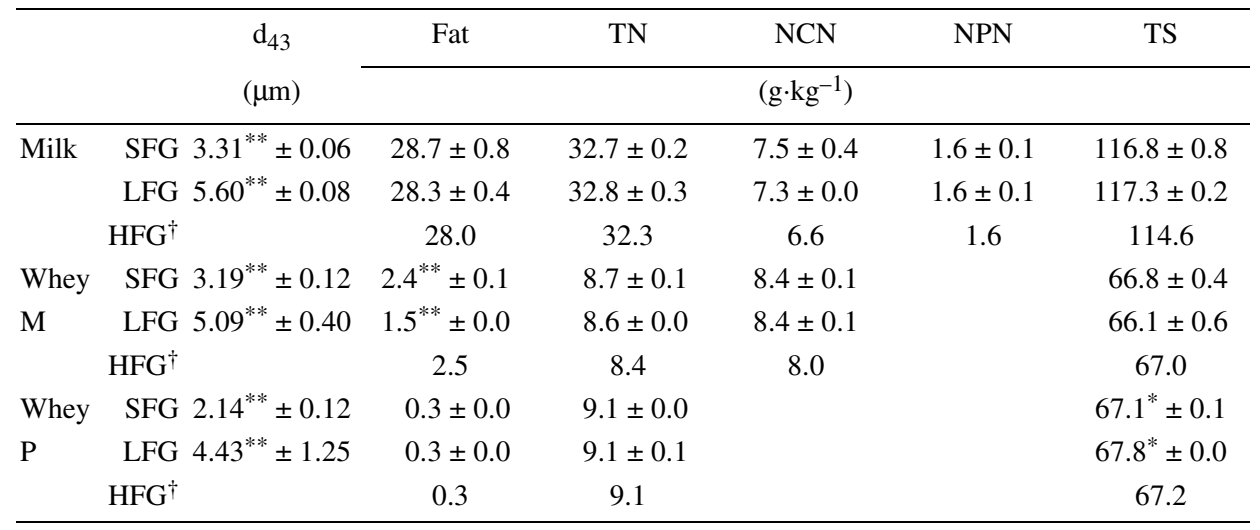

TN: total nitrogen; NCN: non-casein nitrogen; NPN: non-protein nitrogen; TS: total solids (dry matter). SFG: small fat globule milk; LFG: large fat globule milk; HFG: homogenized fat globule milk. Whey M: extracted after moulding; whey P: extracted after pressing. ${ }^{\dagger}$ One manufacture only, not included in statistical analyses. ${ }^{*}$ Significantly different results $(P<0.05) ;{ }^{* *}$ very significantly different results $(P<0.01)$.

\subsection{Cheese yield, fat recovery and Emmental cheese composition}

Corrected cheese yield was $9.1 \pm 0.2 \%$ for SFG cheese vs. $8.9 \pm 0.1 \%$ for $\mathrm{LFG}$ cheese, which was not significantly different. However, fat recovery was very signif- icantly different between the two types of cheeses: $95.7 \pm 0.8 \%$ for LFG vs. $90.9 \pm$ $0.9 \%$ for SFG.

After ripening, the composition of SFG cheese (Tab. II) was consistent with the literature, while LFG cheese had higher TS, $\mathrm{TN}$ and Fat content and less soluble proteins 
Table II. Composition of Emmental cheeses, with different sizes of fat globules, after $52 \mathrm{~d}$ of ripening.

\begin{tabular}{lrrrc}
\hline & \multicolumn{1}{c}{$\mathrm{SFG}$} & \multicolumn{1}{c}{$\mathrm{LFG}$} & \multicolumn{1}{c}{$\mathrm{HFG}^{\dagger}$} & \multicolumn{1}{c}{ Literature $^{\ddagger}$} \\
\hline Fat $\left(\mathrm{g} \cdot \mathrm{kg}^{-1}\right)$ & $292.5^{* *} \pm 4.3$ & $313.8^{* *} \pm 1.8$ & 280 & $298 \pm 11$ \\
$\mathrm{FDM}(\% \mathrm{w} / \mathrm{w})$ & $46.8 \pm 0.7$ & $48.1 \pm 0.2$ & 45.8 & $47.7 \pm 1.1$ \\
$\mathrm{TN}\left(\mathrm{g} \cdot \mathrm{kg}^{-1}\right)$ & $280.5^{* *} \pm 2.6$ & $291.9^{* *} \pm 1.0$ & 277.5 & $282 \pm 7$ \\
$\mathrm{NPN} / \mathrm{TN}(\% \mathrm{w} / \mathrm{w})$ & $9.4^{*} \pm 1.5$ & $6.5^{*} \pm 1.4$ & 16.6 & $12.6 \pm 2.8$ \\
$\mathrm{NCN} / \mathrm{TN}(\% \mathrm{w} / \mathrm{w})$ & $13.5 \pm 3.5$ & $10.7 \pm 0.8$ & 24.6 & $17.3 \pm 4.4$ \\
$\mathrm{TS}\left(\mathrm{g} \cdot \mathrm{kg}^{-1}\right)$ & $625.3^{* *} \pm 4.0$ & $653.2^{* *} \pm 6.4$ & 610.9 & $626 \pm 13$ \\
$\mathrm{MNFS}(\% \mathrm{w} / \mathrm{w})$ & $53.0^{*} \pm 0.6$ & $50.5^{*} \pm 0.8$ & 54.0 & $53.3 \pm 2.6$ \\
$\mathrm{pH}$ & $5.57^{*} \pm 0.0$ & $5.62^{*} \pm 0.0$ & 5.46 & $5.63 \pm 0.11$ \\
$\mathrm{NaCl} / \mathrm{H}_{2} \mathrm{O}(\% \mathrm{w} / \mathrm{w})$ & $2.5 \pm 0.3$ & $1.8 \pm 0.7$ & 2.03 & $1.13 \pm 0.25$ \\
\hline $\mathrm{SFG} / \mathrm{s}$
\end{tabular}

SFG: small fat globule milk; LFG: large fat globule milk; HFG: homogenized fat globule milk. FDM: fat on dry matter; MNFS: moisture in non-fat substance. ${ }^{\circ}$ One manufacture only, not included in statistical analyses. ${ }^{*}[27]$, commercial cheeses. *Significantly different results $(P<0.05)$; **very significantly different results $(P<0.01)$.

and peptide/amino acids than in the literature. Both SFG and LFG cheeses contained more $\mathrm{NaCl}$ than average literature Emmental cheeses; however, large discrepancies can be observed [5].

The FDM and total nitrogen were slightly lower in small fat globule cheeses than in LFG ones. However, Table II shows that the MNFS was significantly different between SFG and LFG cheeses, SFG cheese having 5.0\% more moisture (MNFS) than LFG $52 \mathrm{~d}$ after manufacture. This is consistent with results showing that increasing fat content in Cheddar cheese, i.e., increasing globule number, increases the MNFS [11]. However, the water activity at mid-radius of SFG cheese was lower $(0.980 \pm 0.000)$ than that of LFG cheese $(0.995 \pm 0.007)$, probably due to the higher $\mathrm{NaCl}$ content (even though not significant) of SFG cheese (Tab. II) and its higher content of milk fat globule membrane, too. Peptide and amino acid content (NPN/TN) was in the same order of magnitude as the literature [5]; it was significantly higher in SFG cheeses (Tab. II), which is consistent with results obtained with Camembert cheese [26]. However, soluble protein content ([NCNNPN]/TN) was similar in SFG and LFG cheeses (4.17 vs. $4.15 \%$ ), whereas it was higher in SFG-Camembert cheese [26].
Soluble nitrogen was also found to increase when fat content, i.e., globule content, increased in Cheddar cheese [11]. The HFG cheese had a lower fat content and TS than the SFG cheese, and also higher peptide, amino acid and soluble protein contents. The $\mathrm{pH}$ of the HFG cheese was also lower.

The sugar and organic acid contents in SFG and LFG cheeses at one and $52 \mathrm{~d}$ after manufacture were not significantly different (lactate: $329 \mathrm{mg} \cdot 100 \mathrm{~g}^{-1}$, acetate: $278 \mathrm{mg} \cdot 100 \mathrm{~g}^{-1}$, propionate: $459 \mathrm{mg} \cdot 100 \mathrm{~g}^{-1}$ in SFG cheese after 52 d) and within the range in the literature (lactate: $570 \pm$ $341 \mathrm{mg} \cdot 100 \mathrm{~g}^{-1}$, acetate: $177 \pm 94 \mathrm{mg} \cdot 100 \mathrm{~g}^{-1}$, propionate: $328 \pm 122 \mathrm{mg} \cdot 100 \mathrm{~g}^{-1}$, [27]). However, we observed visually that LFG cheeses presented larger eyes than SFG ones (results not shown). Lipolysis was very significantly higher in LFG cheese (334.1 $\pm 32.7 \mathrm{mg}$ free fatty acid, FFA, per $100 \mathrm{~g}$ fat) than in SFG cheese (91.8 \pm $26.8 \mathrm{mg}$ FFA per $100 \mathrm{~g}$ fat). Table III shows the free fatty acid profile obtained from SFG and LFG cheeses; the results' ranges are consistent with the literature [1, 27]. Proportionally, the percentage of $\mathrm{C} 16$ was lower in SFG $(-12.8 \%)$ and the percentage of C18:1 higher $(+11.9 \%)$ than in LFG, but their overall FFA content was lower. Regarding the fatty acid composition of 
Table III. Free fatty acid content (mg per $100 \mathrm{~g}$ ) in small and large fat globule Emmental cheese, indicating lipolysis $52 \mathrm{~d}$ after manufacture.

\begin{tabular}{lccc}
\hline Fatty acid $^{\dagger}$ & SFG & LFG & Literature $^{\ddagger}$ \\
\hline $4: 0$ & $8.1 \pm 1.20$ & $10.8 \pm 3.11$ & $37 \pm 30$ \\
Iso 5:0 & $1.1 \pm 0.78$ & $2.1 \pm 0.42$ & $2.6 \pm 1.3$ \\
$6: 0$ & $1.2 \pm 0.42$ & $3.2 \pm 0.14$ & $2.9 \pm 1.3$ \\
$8: 0$ & $1.3 \pm 0.49$ & $2.9 \pm 0.07$ & $6.8 \pm 2.6$ \\
$10: 0$ & $2.2 \pm 0.71$ & $7.1 \pm 1.56$ & $13.8 \pm 3.5$ \\
$12: 0$ & $3.2 \pm 0.99$ & $11.6 \pm 2.12$ & $18.0 \pm 5.1$ \\
$14: 0$ & $7.8 \pm 2.62$ & $36.3 \pm 5.23$ & $48.7 \pm 10.7$ \\
$14: 1$ & $0.9 \pm 0.21$ & $2.3 \pm 0.57$ & \\
$15: 0$ & $1.1 \pm 0.42$ & $5.6 \pm 0.99$ & $6.3 \pm 2.2$ \\
$16: 0$ & $26.1 \pm 9.69$ & $132.1 \pm 16.05$ & $117.4 \pm 26.2$ \\
$16: 1$ & $2.8 \pm 0.85$ & $9.7 \pm 0.42$ & $36.5 \pm 11.6$ \\
$18: 0$ & $8.5 \pm 2.62$ & $28.8 \pm 1.70$ & $118.4 \pm 35.5$ \\
$18: 1$ & $23.2 \pm 8.63$ & $69.8 \pm 2.47$ & $10.2 \pm 4.1$ \\
$18: 2$ & $2.6 \pm 0.64$ & $7.9 \pm 1.70$ & \\
$18: 3$ & $1.0 \pm 0.21$ & $1.3 \pm 0.78$ & \\
CLA & $0.7 \pm 0.28$ & $1.7 \pm 0.21$ & \\
$20: 0$ & $0.2 \pm 0.00$ & $0.5 \pm 0.07$ & \\
20:1 & $0.2 \pm 0.00$ & $0.7 \pm 0.14$ & \\
\hline
\end{tabular}

SFG: small fat globule milk; LFG: large fat globule milk. ${ }^{\dagger}[$ Carbon number]:[Number of double bonds]. +11 , commercial cheeses. CLA: conjugated linoleic acids.

total fat in Winter milk, it has been found that the SFG fraction contained more $\mathrm{C} 16$ $(+4.3 \%)$ and less $\mathrm{C} 18: 1(-6.8 \%)$ than the LFG fraction [2], which is the opposite of the FFA trend. Therefore, it seems that lipolysis in SFG cheese favors the production of free C18: 1 compared with other FFA since its content was initially lower in the globules. However, total lipolysis is lower in SFG cheese.

\subsection{Physico-chemical and functional properties of Emmental cheese}

\subsubsection{Fat particles}

In Figure 1, we can see that particles larger than the original fat globules remained in Emmental cheese when the casein matrix had been dissociated. The modal diameter (diameter of the peak of the size distribu- tion) of these particles was $24.7 \pm 4.5 \mu \mathrm{m}$ in SFG vs. $104.1 \pm 58.5$ in LFG. They are likely to correspond to free destabilized fat aggregated with casein strands. The latter represent the way fat globules were arranged within the cheese structure. Figure 2 shows confocal micrographs of SFG and LFG cheese centers. One should keep in mind that since fat globules are tridimensional, these views are affected by the location and viewing direction of the sample. However, the difference in fat globule size can be readily observed, as well as the presence of globule aggregates and so-called free fat, especially in LFG. Moreover, fat structures clearly seem preferentially oriented. It is clear that milk fat is embedded within the casein matrix, but it seems to have lost its globular structure most of the time due to heating and pressing steps, resulting in some flattened free fat areas. Using electron 

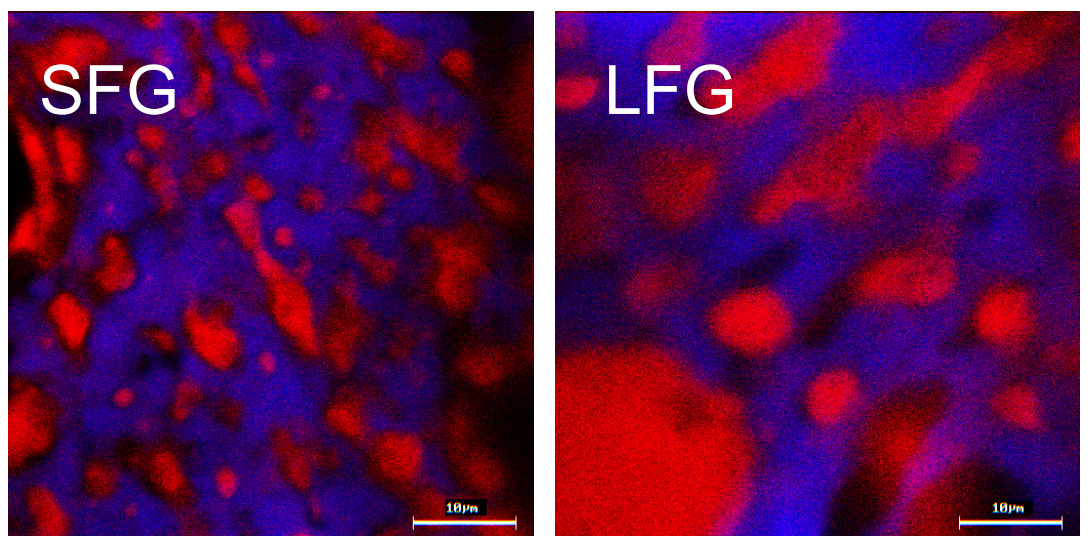

Figure 2. Confocal laser scanning micrographs of milk fat particles at the center of Emmental cheeses produced using small (SFG) and large (LFG) native milk fat globules. Fat is coded in red and proteins in blue. Scale bar represents $10 \mu \mathrm{m}$.

microscopy, other authors observed more intact milk fat globules within Emmental cheese without free fat observation [5] or large masses of fat globules [30]. However, sample preparation using this technique may have induced artifacts. Some smooth zones devoid of fat globules were observed and interpreted as voids in the matrix; these zones may well correspond to destabilized fat inclusions. Mahdjoub et al. used 3D magnetic resonance micro-imaging to observe the Emmental curd grain structure [20]. Numerous fat inclusions were located only at the curd granule boundaries after $24 \mathrm{~h}$ of ripening and the difference in fat content between the curd joints and grains increased during ripening and storage. Our confocal views are similar to others obtained with Cheddar cheese [12], where $80 \%$ of the globules remained spherical but others were larger than $10 \mu \mathrm{m}$ and less spherical. In full-fat Cheddar cheese, clumping and coalescence are significant, and various sizes and shapes of fat globules are observed [11]. The clumping of fat globules is certainly due to the shearing of the fat globule membrane during milk handling and the cheese-making process and the subsequent coalescence of the partially denuded liquid fat globules when the curd is warm [11]. This fat structure is different from that we observed in Camembert cheese, where fat essentially remained globular but aggregated [26].

\subsubsection{Rheological properties}

The rheological properties of the Emmental cheeses are presented Table IV. The stiffness of Emmental cheese did not vary significantly according to the native fat globule size. However, the SFG cheeses were very significantly less flexible (lower fracture stress) and less firm (lower fracture Hencky's strain) than the LFG ones. The flexibility of LFG cheese was higher than in the literature for regular Emmental cheese, whereas the firmness of the SFG cheese was lower [5]. The lower firmness of SFG cheese is certainly due to its greater moisture content (MNFS). However, it could also be related to the finer dispersion of small fat globules and smaller free fat units within the matrix (Fig. 2), corresponding to more numerous weak points in the casein network. Roughly, the SFG average diameter being about half the LFG diameter, this would correspond to eight times more globules 


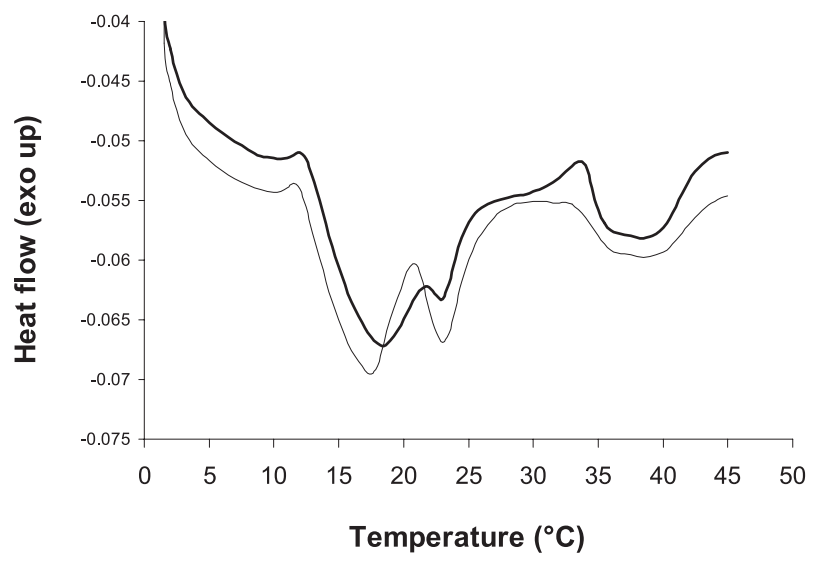

Figure 3. Melting profile of small (thin line) and large (thick line) milk fat globule Emmental cheese recorded by differential scanning calorimetry.

Table IV. Rheological characteristics of Emmental curd made with small (SFG) or large (LFG) fat globules.

\begin{tabular}{lccc}
\hline & SFG & LFG & Literature range $^{\dagger}$ \\
\hline Stiffness $\left(\mathrm{N} \cdot \mathrm{m}^{-1}\right)$ & $6.76 \times 10^{3} \pm 0.88 \times 10^{3}$ & $7.02 \times 10^{3} \pm 2.21 \times 10^{3}$ & \\
Fracture stress $(\mathrm{Pa})$ & $1.35 \times 10^{5 *} \pm 0.17 \times 10^{5}$ & $2.34 \times 10^{5^{*}} \pm 0.18 \times 10^{5}$ & $1.11 \times 10^{5}-1.85 \times 10^{5}$ \\
Fracture Hencky's strain & $0.74^{*} \pm 0.03$ & $1.10^{*} \pm 0.1$ & $0.87-1.56$ \\
\hline
\end{tabular}

Ten repetitions were done. ${ }^{\dagger}[5]$, three different ripened cheeses. *Very significantly different results $(P<0.01)$.

in the SFG curd. The interglobular distance (or mean free distance between fat globules) can be estimated from fat globule diameter and fat volume fraction as previously done for Camembert cheese [26], even though part of the globular structure is lost in Emmental cheese: $\sim 1.8 \mu \mathrm{m}$ for SFG cheese vs. $\sim 3.3 \mu \mathrm{m}$ for LFG cheese. Moreover, fat globule aggregates and free fat appear to be more dispersed, i.e. more numerous, in SFG cheeses than in LFG ones (Fig. 2). Thinner casein strands are thus formed between the globule pores in SFG, resulting in a more fragile structure. We should note that rheological differences between SFG and LFG Emmental cheeses are different from those obtained with Camembert cheese curd, where no difference was observed regarding flexibility whereas the stiffness was lower for SFG cheese. This stresses the impact of fat and matrix structure on rheological properties: the globular structure of fat contributed to affect stiffness, whereas the free fat structure contributed to affect flexibility.

\subsubsection{DSC melting profile}

Figure 3 shows typical melting profiles of SFG and LFG cheese obtained by DSC using a heating rate of $10^{\circ} \mathrm{C} \cdot \mathrm{min}^{-1}$. No difference was observed whether a sample was cut from the center, mid-radius or periphery of the cheese (e.g., the final melting temperature of SFG cheeses was $41.9 \pm 1{ }^{\circ} \mathrm{C}$ in the cheese center, $43.0 \pm 2.1^{\circ} \mathrm{C}$ at the midradius and $42.7 \pm 1.4{ }^{\circ} \mathrm{C}$ at the cheese 
periphery). The cheese melting profile is related to the thermal properties of the triglycerides contained in the fat globules, and to the globule or free fat structure. It has been shown that partial triglyceride crystallization occurred during ripening of semihard cheese [4]. Milk fat contains three classes of triglycerides that present different melting temperature ranges: the low-, medium- and high-melting fractions. In the present study, we observed a split of the endothermous peak corresponding to the medium-melting fraction for both cheeses. Famelart et al. [5], however, observed a homogeneous medium-melting peak without a split, but their heating rate was $3{ }^{\circ} \mathrm{C} \cdot \mathrm{min}^{-1}$, which can affect the DSC profile. Since the split we observed was more pronounced for the SFG cheese, we can hypothesize that at fast heating, the milk fat structure (free fat inclusions or more or less small globules) influences melting. The first part of the medium-melting fusion peak might correspond to free fat melting, while the second part might correspond to the melting of remaining fat globules for which heat transfer would be less efficient due to fat dispersion. Like Famelart et al., we observed a residual endothermic signal above $40{ }^{\circ} \mathrm{C}$ [5]. However, the anhydrous milk fat extracted from the Emmental cheeses finished melting at around $40.5^{\circ} \mathrm{C}$. The residual endotherm at higher temperatures can thus correspond to the rupture of matrix links at a relatively low temperature, presumably hydrogen links [5].

The so-called offset melting temperature of low- and high-melting triglyceride fractions in Emmental cheese increased with the size of the native fat globules (Fig. 4). The difference between SFG and LFG was significant for each manufacture (mean standard deviation: $0.15^{\circ} \mathrm{C}$ ). It has been found, using recombined fat globules of various sizes with milk fat or model fat, that a deeper supercooling is needed to crystallize smaller fat globules, that also have a lower crystallization rate [19, 34]. Moreover, the composition of the interface has been found to affect the crystallization properties

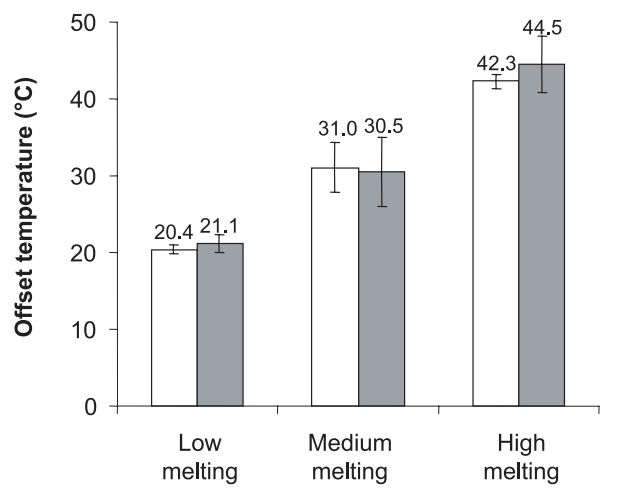

Figure 4. Offset melting temperatures (low-, medium-, high-melting fractions) of small (white) and large (grey) milk fat globule Emmental cheeses, calculated from the differential scanning calorimetry curves.

of model fat globules [19], i.e., in Emmental cheese, the native membrane or free interface boundary can affect the fat melting profile. Finally, these phenomena should be enhanced for SFG in Emmental cheese since globular fat and free fat are more dispersed than for LFG (Figs. 1 and 2), which could explain the DSC results.

\subsubsection{Functional properties}

Regarding functional properties of Emmental cheese, oiling-off was not significantly different in SFG vs. LFG cheese $(12.6 \pm 1.4 \%$ vs. $12.9 \pm 1.9 \%)$, even though LFG cheese contained $7.3 \%$ more fat than SFG (Tab. II), and even though this fat seemed to appear as larger free fat inclusions (Fig. 2). Moreover, our values are similar to those obtained using regular Emmental cheese: $13.5 \pm 2.7 \%$ [27]. This result suggests that oiling-off may not be governed by fat structure only, but also by the protein matrix structure. Figure 5 shows the functional properties of Emmental cheeses. The melting coefficient was similar to Richoux et al. (1.82 \pm 0.48$)[27]$ and lower than Famelart et al. (3.50-3.86) [5], while a great discrepancy in stretching 


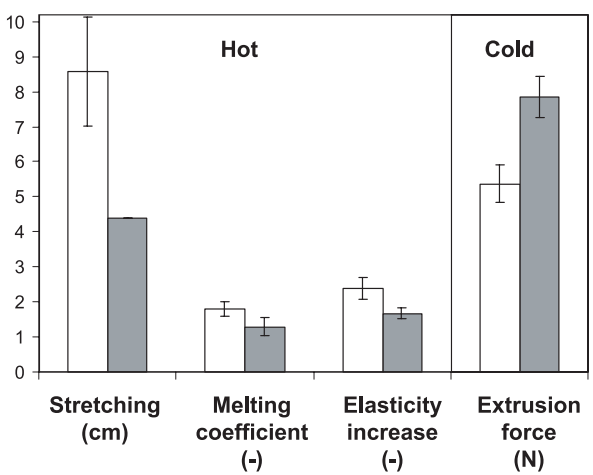

Figure 5. Functional properties of small (white) and large (grey) milk fat globule Emmental cheese, measured hot or cold. Elasticity increase was calculated on defatted cheese.

measurements was reported in the literature $(28.3 \pm 23.5 \mathrm{~cm},[27] ; 11.7-19.4 \mathrm{~cm},[5])$. SFG cheese presented significantly higher stretching and elastic increase and tended to melt more than LFG cheese. Its extrusion force was significantly lower than that of LFG cheese. These results are consistent with the lower firmness of the SFG cheese, as well as with the lower melting temperature measured by DSC of the latter $[14,15]$. Indeed, the cheese meltability is known to be due to the melting of milk fat, followed by collapsing of the cheese matrix due to reduced support by the fat [18]. This collapse can occur faster in SFG cheeses, because the interglobular (or inter-free fat units) distance is smaller and thus the casein strands are thinner [26]. Finally, SFG cheese appeared to be yellower than LFG cheese: the yellow index was $33.8 \pm 0.9$ for SFG vs. $34.7 \pm 0.7$ for $\mathrm{LFG}$ and the Lparameter (clearness) was $74.9 \pm 1.0$ for SFG vs. $68.9 \pm 0.3$ for LFG. Famelart et al. [5] reported $\mathrm{L}$ in the range 74.6-77.0 (variations due to fat composition via cow feed); the LFG cheese was thus much darker. This can be explained by the lower light diffraction by LFG that results in a more intense color perception. The same color difference was observed with SFG and LFG Camembert cheeses [26]. The possibility of a different $\beta$-carotene content in SFG and LFG should be investigated.

Richoux et al. have shown that stretching and melting were highly dependent parameters, and that oiling-off was positively correlated to both of them [27]. The key role of oiling-off on melting properties has previously been demonstrated regarding Mozzarella cheese [31]. MNFS, FDM, NCN/TN, and $\mathrm{Ca}$ content are known to affect the melting and oiling-off of cheeses. However, one should not neglect the influence of technological practice and processes, besides cheese composition [27]. Famelart et al. have shown that higher TS, lower cheese acidity and slightly larger milk fat globules resulted in a lower culinary aptitude and a higher flexibility at room temperature [5]. Our results are consistent with the latter, since the LFG cheeses were less acid, less humid, more flexible and presented lower melting and stretching. Our results are also consistent with their finding that (i) the Emmental cheese stiffness increased when the proteolysis decreased, which was related to cheeses that were less yellow; (ii) the firmness increased when the water content decreased and the $\mathrm{NaCl}$ and ash increased, resulting in a lower spreading ability of the melt; and (iii) the flexibility increased when the cheese melt was more elastic and the $\mathrm{pH}$ was lower [5]. Overall, water content, fat content and NPN are positive regarding culinary aptitudes, whereas $\mathrm{NaCl}, \mathrm{Ca}$ and soluble nitrogen have a detrimental effect. Therefore, the rheological and functional differences observed in the present study for Emmental cheeses with two different sizes of native fat globules appear to be directly related to the compositional differences (MNFS, TS and $\mathrm{pH}$ ) resulting from the use of different fat globules with a single manufacturing process. Other experiments are currently being carried out in order to produce cheeses with similar MNFS and different sizes of milk fat globules, in order to restrict compositional differences and understand the effect of fat globule size in a more straightforward manner. 


\subsection{Moisture and lipolysis}

Fat is known to be important in allowing moisture to be retained in cheese [22], which is linked to the ability of the native milk fat globule membrane to bind water. For a given fat content, SFG have a greater total surface area of MFGM: $\sim 2.2 \mathrm{~m}^{2} \cdot \mathrm{g}^{-1}$ for SFG vs. $\sim 1.3 \mathrm{~m}^{2} \cdot \mathrm{g}^{-1}$ for LFG in this study, i.e., the surface is two-fold when the diameter is halved. Moreover, considering Figures 1 and 2, it seems that SFG formed less aggregates and free fat than LFG, which would also contribute to their greater water-binding ability since more natural membrane would have been preserved. The free fat in LFG cheese is likely to facilitate whey draining. These results are consistent with the higher MNFS observed for SFG. This increase in water is also likely to explain the greater proteolysis of SFG compared with LFG (higher NPN/TN), as proteolytic enzymatic activities are enhanced, even though the water activity is slightly lower in SFG cheese. The worse fat recovery for SFG suggests that small globules are hardly entrapped in the casein matrix and lost in whey (Tab. II), which is converse to results obtained with Camembert cheese [26]. The higher lipolysis in LFG cheese compared with SFG cheese can be explained by the apparently higher free fat (large fat globules are easier to destabilize; Figs. 1 and 2). This fat is not likely to be protected by any membrane, which makes the access of lipases easier since the fat interface is the specific site for their activity. The higher availability of water (higher $\mathrm{a}_{\mathrm{w}}$ ) in LFG could also explain the greater lipolysis. One should note that lipolysis was dramatically higher in the Emmental cheese produced with homogenized milk fat globules instead of native globules: $1156 \mathrm{mg}$ FFA per $100 \mathrm{~g}$ fat for HFG cheese vs. 91.8 for SFG cheese; moreover, the smell of the cheese made with homogenized fat globules was very rancid and unacceptable from a consumer viewpoint. This shows that fat destabilization is of tremendous importance regarding lipolysis, and that the use of small native milk fat globules cannot be compared with homogenized ones.

We should mention that part of the present results could be due to physico-chemical and biochemical differences among milk fat globules according to their size. Indeed, when artificial recombined fat globules are created by emulsifying milk fat in skimmed milk, they have the same composition and their membrane is composed of caseins, whatever their size. Conversely, native milk fat globule composition differ according to their size [2]. This could induce differences in cheese flavor, as different aroma precursors exist in the two fractions. Specific studies of lipase activity and aroma compounds generated from small and large native milk fat globules should be carried out.

\section{CONCLUSION}

The size of native milk fat globules was found to affect the physico-chemical and functional properties of Emmental cheese. The use of smaller milk fat globules resulted in cheese with more moisture and a more melting texture, which is consistent with results previously obtained regarding Camembert cheese, even though we have shown that the fat structure is different in both cheeses. This suggests the possibility of developing products with new technological and functional properties, that have improved characteristics compared with the use of homogenized globules. These results can be explained by the larger surface area of milk fat globules and free-fat particles and the thinner casein strands in small fat globule cheese. Experiments are being carried out in our laboratory to further characterize the structure of milk fat in various cheese matrices and its consequence regarding lipolytic activity.

Acknowledgements: A. Thierry and M.B. Maillard are acknowledged for sugar and organic acid analysis. C. Garnier is acknowledged for performing CLSM observations. M.H. Famelart 
and V. Gagnaire are acknowledged for their help regarding rheological data analysis and manuscript discussion. The helpful discussions with G. Brulé were appreciated. We thank E. Beaucher for technical assistance. J.R. Kerjean and R. Richoux (ITFF) are acknowledged for their help regarding analysis of functional properties. We thank the referees for their guidance in improving the manuscript.

\section{REFERENCES}

[1] Berdagué J.L., Grappin R., DelacroixBuchet A., Chaillet B., Caractérisation de l'emmental « Grand Cru » français. I. Composition physico-chimique, Lait 70 (1990) $1-14$.

[2] Briard V., Leconte N., Michel F., Michalski M.C., The fatty acid composition of small and large naturally occuring milk fat globules, Eur. J. Lipid Sci. Technol. 105 (2003) 677-682.

[3] de Jong C., Badings H.T., Determination of free fatty acids in milk and cheese. Procedures for extraction, clean up, and capillary gas chromatographic analysis, J. High Res. Chromatogr. 13 (1990) 94-98.

[4] Dufour E., Mazerolles G., Devaux M.F., Duboz G., Duployer M.H., Mouhous Riou N., Phase transition of triglycerides during semi-hard cheese ripening, Int. Dairy J. 10 (2000) 81-93.

[5] Famelart M.H., Le Graet Y., Michel F., Richoux R., Riaublanc A., Évaluation des méthodes d'appréciation des propriétés fonctionnelles des fromages d'emmental de l'Ouest de la France, Lait 82 (2002) 225245.

[6] FIL, Fromage et fromage fondu : détermination de la teneur en matière grasse, standard 5B, Int. Dairy Fed., Brussels, Belgium, 1986.

[7] FIL, Lait, crème et lait concentré non sucré, détermination de la matière sèche, standard 21B, Int. Dairy Fed., Brussels, Belgium, 1987.

[8] FIL, Détermination de la teneur en azote, standard 20B, Int. Dairy Fed., Brussels, Belgium, 1993.

[9] Goudédranche H., Maubois J.L., Fauquant J., Produits, en particulier laitiers, comprenant des fractions sélectionnées de globules gras, obtention et applications, Brevet FR. 2.776. 208.-A1, 24 p., 1998.

[10] Gripon J.C., Desmazeaud M., Le Bars D., Bergère J.L., Étude du rôle des micro-organismes et de leurs enzymes dans la matura- tion des fromages. II. Influence de la présure commerciale, Lait 55 (1975) 502-516.

[11] Guinee T.P., Auty M.A.E., Fenelon M.A., The effect of fat content on the rheology, microstructure and heat-induced functional characteristics of Cheddar cheese, Int. Dairy J. 10 (2000) 277-288.

[12] Gunasekaran S., Ding K., Three-dimensional characteristics of fat globules in Cheddar cheese, J. Dairy Sci. 82 (1999) 1890-1896.

[13] Herbert S., Bouchet B., Riaublanc A., Dufour E., Gallant D.J., Multiple fluorescence labelling of proteins, lipids and whey in dairy products using confocal microscopy, Lait 79 (1999) 567-575.

[14] Jameson G.W., Cheese with less fat, Austr. J. Dairy Technol. 1990 (1990) 93-98.

[15] Jaros D., Petrag J., Rohm H., Ulberth F., Milk fat composition affects mechanical and rheological properties of processed cheese, Appl. Rheol. 11 (2001) 19-25.

[16] Keenan T.W., Dylewski D.P., Intracellular origin of milk lipid globules and the nature and structure of the milk lipid globule membrane, in: Fox P.F. (Ed.), Advanced Dairy Chemistry, Vol. 2: Lipids, 2nd edn., Chapman \& Hall, London, UK, 1995, pp. 89-130.

[17] Kuchroo T.K., Fox P.F., Soluble nitrogen in Cheddar cheese: comparison of extraction procedures, Milchwissenschaft 37 (1982) 331-335

[18] Lefevere I., Dewettinck K., Huyghebaert A., Cheese fat as a driving force in cheese flow upon melting, Milchwissenschaft 55 (2000) 563-566.

[19] Lopez C., Contribution à l'étude de la cristallisation des triacylglycérols : application aux émulsions laitières, Thesis, Université Pierre et Marie Curie, Paris, 2001.

[20] Mahdjoub R., Molegnana J., Seurin M.J., Briguet A., High resolution magnetic resonance imaging evaluation of cheese, J. Food Sci. 68 (2003) 1982-1984.

[21] Maubois J.L., Mocquot G., Comment ramener à la même teneur en substance sèche des fabrications de fromage en vue de comparer les « rendements » respectifs du lait en fromage, Revue Laitière Française 239 (1967) $15-18$.

[22] McMahon D.J., Oberg C.J., Influence of fat, moisture and salt on functional properties of Mozzarella cheese, Austr. J. Dairy Technol. 53 (1998) 98-101.

[23] Michalski M.C., Briard V., Michel F., Optical parameters of milk fat globules for laser light scattering measurements, Lait 81 (2001) 787-796. 
[24] Michalski M.C., Michel F., Briard V., On the size distribution and zeta-potential of homogenized milk fat globules, in: Anton M. (Ed.), Food Emulsions and Dispersions, Research Signpost, Kerala, India, 2002, pp. 49-65.

[25] Michalski M.C., Michel F., Sainmont D., Briard V., Apparent zeta-potential as a tool to assess mechanical damages to the milk fat globule membrane, Colloids Surfaces B: Biointerfaces 23 (2002) 23-30.

[26] Michalski M.C., Gassi J.Y., Famelart M.H., Leconte N., Camier B., Michel F., Briard V., The size of native milk fat globules affects physico-chemical and sensory properties of Camembert cheese, Lait 83 (2003) 131-143.

[27] Richoux R., Roset G., Famelart M.H., Kerjean J.R., Diversité de quelques propriétés fonctionnelles à chaud de l'emmental français, Lait 81 (2001) 547-559.

[28] Rohm H., Jaros D., Colour of hard cheese. 1. Description of colour properties and effects of maturation, Z. Lebensm. -Untersuch. Forsch. 203 (1996) 241-244.
[29] Roset G., Richoux R., Aubert L., Kerjean J.R., Outils de mesures des propriétés thermo-fonctionnelles de l'emmental français, Compte rendu du programme région Bretagne, ITFF number 1045, operation A1C730, 2002.

[30] Rousseau M., Le Gallo C., Étude de la structure de l'emmental au cours de la fabrication, par la technique de la microscopie électronique à balayage, Lait 70 (1990) 55-66.

[31] Rudan M.A., Barbano D.M., Yun J., Kinstedt P.S., Effects of fat reduction on chemical composition, proteolysis, functionality and yield of Mozarella cheese, J. Dairy Sci. 82 (1999) 661-672.

[32] van Vliet T., Inventory of test methods, in: Rheological and fracture properties of cheese, Bull. FIL-IDF 268, 1991, pp. 16-25.

[33] Walstra P., Physical chemistry of milk fat globules, in: Fox P.F. (Ed.), Advanced Dairy Chemistry, Vol. 2: Lipids, 2nd edn., Chapman \& Hall, London, 1995, pp. 131-178.

[34] Walstra P., van Beresteyn E.C.H., Crystallization of milk fat in the emulsified state, Neth. Milk Dairy J. 29 (1975) 35-65. 